MACHINE BUILDING

PROCESS METALLURGY

MATERIALS SCIENCE

UDC 621.785.53:669.15

K.O. Kostyk, PhD, Assoc.Prof.

National Technical University “Kharkiv Polytechnic Institute”, 21 Frunze Str., 61002 Kharkiv, Ukraine; e-mail: eklitus@yandex.ru

\title{
RESEARCH OF INFLUENCE OF GAS NITRIDING DURATION ON FORMATION OF DIFFUSION LAYER OF STEEL 20Kh2N4A
}

\begin{abstract}
К.О. Костик. Дослідження впливу тривалості газового азотування на формування дифузійного шару сталі 20X2H4А. Актуальним є проведення досліджень процесу газового азотування, яке дозволяє отримувати високу якість поверхні стальних деталей і має широке застосування у масовому виробництві. Метою дослідження $\epsilon$ вивчення впливу режимів газового азотування на структуру і властивості легованої сталі. Матеріалом дослідження в даній роботі $є$ сталь 20X2H4А. Азотування зразків здійснювали в шахтній печі при температурі $510 \ldots .530{ }^{\circ} \mathrm{C}$ протягом $35,40,46$ та 48 годин. Встановлено, що попередня термічна обробка перед азотуванням легованої сталі 20X2Н4А забезпечує твердість серцевини виробів до 279...321 HV за рахунок формування перліто-сорбітної структури з карбідами легувальних елементів. Результати дослідження показали, що при збільшенні тривалості азотування від 35 до 48 годин при $510 . .530{ }^{\circ} \mathrm{C}$ збільшується глибина азотованого шару від 0,35 до 0,55 мм відповідно з поверхневою твердістю до 648 МПа при максимальній глибині шару. Результати досліджень можуть бути використані на виробництві й у науково-дослідних роботах.

Ключові слова: азотування, легована сталь, дифузійний шар, поверхнева твердість.

K.O. Kostyk. Research of influence of gas nitriding duration on formation of diffusion layer of steel 20Kh2N4A. The research of the gas nitriding process, which allows to obtain a high surface quality of steel parts and has a wide application in mass production, is relevant. Aim of the research is to study the influence of gas nitriding modes on the structure and properties of alloy steel. The research material in this work is steel $20 \mathrm{Kh} 2 \mathrm{~N} 4 \mathrm{~A}$. Nitriding of the samples is carried out in a shaft furnace at the temperature of $510 \ldots 530{ }^{\circ} \mathrm{C}$ during $35,40,46$ and $48 \mathrm{~h}$. It is found that the alloy steel $20 \mathrm{Kh} 2 \mathrm{~N} 4 \mathrm{~A}$ preliminary heat treatment before nitriding provides the hardness of products core to $279 \ldots 321 \mathrm{HV}$ due to the formation of perlitesorta structure with carbides of alloying elements. The results show that increasing the duration of nitriding from 35 to 48 hours at $510 \ldots 530^{\circ} \mathrm{C}$ increases the depth of nitrided layer from 0,35 to $0,55 \mathrm{~mm}$ with surface hardness up to $648 \mathrm{MPa}$ at the maximum depth of the layer. The results of this research can be used in industry and research works.

Keywords: nitriding, alloy steel, diffusion layer, surface hardness.
\end{abstract}

Introduction. Due to the rapid development of techniques the issues of improvement of reliability and durability of machine parts, devices, systems, improvement of their quality and performance,

DOI 10.15276/opu.2.46.2015.04

(C) 2015 The Authors. This is an open access article under the CC BY license (http://creativecommons.org/licenses/by/4.0/). 
as well as issues of metals economy and resistance to corrosion and wear of machine parts become extremely relevant. The solution to these problems primarily are associated with the strengthening of surface layers of products. Their role in the longevity of machinery, equipment and others particularly increases now, because the development of most industries (aviation, rocket, thermal power, nuclear power, electronics) is associated with increase of loads, temperature, aggressive environments in which detail operates [1...3].

Literature review. There are various ways to change the properties of the surface to the desired direction. There are many methods of chemical and thermal processing (CTP), such as saturation at powder environment, at liquid, gas method and saturation in a vacuum. A unique set of steel products properties is achieved due to nitriding, which consists in saturation of steel boundary layer with nitrogen when heated in a suitable environment from 500 to $1200^{\circ} \mathrm{C}$.

In recent decades, in global industrial practice it was noted the increasing interest in processes of low temperature saturation of iron-based alloys with nitrogen or both nitrogen and carbon. At the same time there are a lot of reports of extremely high effectiveness of wide implementation of the results of these processes in the production cycle for many companies, including leading industrial companies and associations all around the world. There is a clear tendency to replace traditional high-temperature methods of cementation and nitrocementation by nitriding and more often carbonitriding concerning details of basic nomenclature of engineering production [4...6].

Nowadays, further studies of this CTP are conducted which allows to obtain high quality of surface and widespread use in mass production.

Saturation of alloys with nitrogen changes the state of structure and thus the static and dynamic strength, wear resistance, deformability and corrosion properties of these materials. If the processing temperature does not exceed $600{ }^{\circ} \mathrm{C}$, the structural changes similar to those which occur as a result austenization during quenching do not occur. This allows to carry out the cooling with any rate without the risk of martensite formation. For this reason, unlike hardening, deformation and warping of nitrided parts and tools are received minor. So, the further processing can be both simplified and completely abolished $[7,8]$.

The influence of these processes on strength, wear resistance and corrosion resistance opens up the technical possibility of their use in almost all industries, as it can be seen, for example, in the presence of thousands of plants for nitriding, which are used in many countries of the world.

Aim of the Research is to study the influence of gas nitriding modes on the structure and properties of alloy steel.

Main body. The tested material and methodology of nitriding. The research material in this work is steel 20Kh2N4A. From it there are made gears, shaft gears, toes and other highly responsible and highly loaded details, which are required for high strength and surface hardness with the plastic and viscous core, operating under shock loads and at subzero temperature. Before CTP the surface of studied samples is purified from traces of scale, rust, grease and other contaminants. Then it is polished with following degreasing by $96 \%$ alcohol.

For steel $20 \mathrm{Kh} 2 \mathrm{~N} 4 \mathrm{~A}$ the hardening is made at $890^{\circ} \mathrm{C}$ for $210 \mathrm{~min}$. with cooling in oil. The issue is carried out for $270 \mathrm{~min}$. at $550{ }^{\circ} \mathrm{C}$ with cooling in furnace up to $\sim 450{ }^{\circ} \mathrm{C}$ and then on the air, after which the microstructure - sorbitol - is formed.

Nitriding of samples is performed in the shaft furnace SShAM-12.12/7 at $510 \ldots 530^{\circ} \mathrm{C}$ for 35 , 40, 46 and $48 \mathrm{~h}$.

Previous heat treatment of nitriding details. Previous heat treatment and tolerance is usually made in the rough blanks and for the parts of small section - directly in the rolling bars (for the diameter less than $50 \mathrm{~mm}$ ).

Preliminary processing does not affect the hardness and depth of the nitrided layer. The hardness of the nitrided layer of structural steels can be enhanced by combining nitriding with subsequent induction hardening.

In all cases, temperature tolerance after hardening should exceed nitriding temperature at $40 \ldots 70^{\circ} \mathrm{C}$ to eliminate the influence of phase transformations of the core parts on the quality of nitriding. 
For critical parts with complex configuration before alloying it is recommended to do stabilizing tolerance to relieve internal stresses arising in the product during cutting and can be a source of strain during the nitriding. The stabilizing tolerance is recommended at $550 \ldots 600^{\circ} \mathrm{C}$ for $3 \ldots 10$ hours followed by slow cooling (furnace, air).

In general, the technological process of manufacturing of nitriding products can be presented in the form of the following consecutive stages:

- preliminary heat treatment to provide the necessary complex of mechanical properties for steel;

- mechanical processing of parts, including grinding;

— protection of places that are not subject of nitriding;

— nitriding;

- final grinding or bringing the product in accordance to the given tolerances.

Shaft work materials are normalized by loading them into the furnace at temperature $\leq 295{ }^{\circ} \mathrm{C}$ followed by its increase during $16 \mathrm{~h}$. to $900 \ldots 920^{\circ} \mathrm{C}$ and endurance for $9 \mathrm{~h}$. Shafts that has been normalized, are cooled by fans for $2,5 \ldots 3 \mathrm{~h}$. and then by air for $5 \mathrm{~h}$. After normalization the tolerance is carried out in the same furnace. Details are loaded into the furnace at the temperature of not more than $290{ }^{\circ} \mathrm{C}$. Heat of the furnace to a temperature $660 \ldots 680{ }^{\circ} \mathrm{C}$ lasts at least $5 \mathrm{~h}$. followed by exposure for $6 \mathrm{~h}$.; cooling of the shaft furnace is up to the temperature $300^{\circ} \mathrm{C}$. Then shafts are exposed again by stabilizing tolerance, so the parts are loaded again into the furnace at temperature up to $105{ }^{\circ} \mathrm{C}$ with its subsequent increase to $560^{\circ} \mathrm{C}$ and endurance for $4,5 \mathrm{~h}$. and subsequent cooling to a temperature of $300{ }^{\circ} \mathrm{C}$. Later shafts are cooled on the air. Parts that have been stabilized, again are subjected to mechanical processing with preserving tolerance under nitriding equal to $0,5 \mathrm{~mm}$ in diameter.

To obtain high mechanical properties of the core and the smallest elementary technological residual stresses after mechanical processing the shafts of alloy steel $20 \mathrm{Kh} 2 \mathrm{~N} 4 \mathrm{~A}$ are subjected to the improvement - hardening at $890{ }^{\circ} \mathrm{C}$ with cooling in oil with subsequent high tolerance. The rate of cooling to $300{ }^{\circ} \mathrm{C}$ during hardening should be no more than $75^{\circ} \mathrm{C} / \mathrm{h}$. Then shafts are subjected to the tolerance, so details are loaded into the furnace again at the temperature of $105{ }^{\circ} \mathrm{C}$ with its subsequent increase to $560{ }^{\circ} \mathrm{C}$ and endurance for $4,5 \mathrm{~h}$. and subsequent cooling to the temperature of $300{ }^{\circ} \mathrm{C}$. Later shafts are cooled on the air.

During the thermal hardening of the detail the following conversions of structure occur.

In the initial state the steel structure is a ferrite plus perlite. Heating to the hardening temperature ensures austenite structure. As a result of hardening cooling the structure martensite is formed. As a result of high temperature operation the steel has structure of sorbitol tolerance which provides high viscosity of core. To get the given high hardness of detail, the corrosion and wear resistances we carry out the operation - nitriding, in consequence of which the structure on the surface of the part is formed consisting of nitrogen carbide, nickel, vanadium, tungsten and chromium. The structure in the core is viscous sorbitol tolerance.

Thus, we get viscous core and high hardness and wear resistance over the entire surface of the detail.

Results. Optimal duration of nitriding. Traditionally the temperature of nitrided products at enterprises is $510 \ldots 550{ }^{\circ} \mathrm{C}$. To select the optimal duration of nitriding process the time was set at intervals from 35 to $48 \mathrm{~h}$. Samples were saturated with ammonia in the furnace SShAM at $510 \ldots 530^{\circ} \mathrm{C}$. The optimal duration of nitriding is assumed as such a time that provides the greatest thickness of the nitrided layer with high surface hardness.

The total depth of the nitrided layer depending on the length of CTP is shown at Fig. 1. As can be seen (Fig. 1) increasing of the nitriding duration of at $510 \ldots 530^{\circ} \mathrm{C}$ increases the nitrided layer thickness. During this time, carbides and nitrides of alloying elements do not have time to grow to sizes which inhibit further diffusion of nitrogen and carbon deep into the metal.

The presence of carbon and alloying elements increases the number of defects by the crystal lattice distortion. And as it is known [6], the more defects, the faster diffusion. For steel 20Kh2N4A the diffusion layer is from 0,35 to $0,55 \mathrm{~mm}$ with increasing of duration of CTP from 35 to $48 \mathrm{~h}$., respectively (Table). 
The thickness of the diffusion layer of steel 20Kh2N4A after gas nitriding

\begin{tabular}{c|c|c}
\hline Duration of gas nitriding, $h$. & Thickness of the nitrided layer, mm & Surface hardness, HV \\
\hline 35 & 0,35 & 620 \\
\hline 40 & 0,45 & 635 \\
\hline 46 & 0,5 & 644 \\
\hline 48 & 0,55 & 648 \\
\hline
\end{tabular}

In the study of changes in micro hardness and depth of the nitrided of layers steel $20 \mathrm{Kh} 2 \mathrm{~N} 4 \mathrm{~A}$ after nitriding at $510 \ldots 530^{\circ} \mathrm{C}$ at different process time it can be seen that the microhardness and depth of the nitrided layer change. The samples 46 and $48 \mathrm{~h}$. of exposure have the highest surface hardness (Fig. 2), the total thickness of the diffusion layer is sufficient. The thickness of layer significantly reduces and surface hardness remains satisfactory at duration of $40 \mathrm{~h}$. The thickness and surface hardness significantly reduce remaining unsatisfactory for nitriding at duration of $35 \mathrm{~h}$. Taking into account the optimal ratio of surface hardness and thickness of the nitrided layers, we choose nitriding duration of $48 \mathrm{~h}$. at $510 \ldots 530{ }^{\circ} \mathrm{C}$.

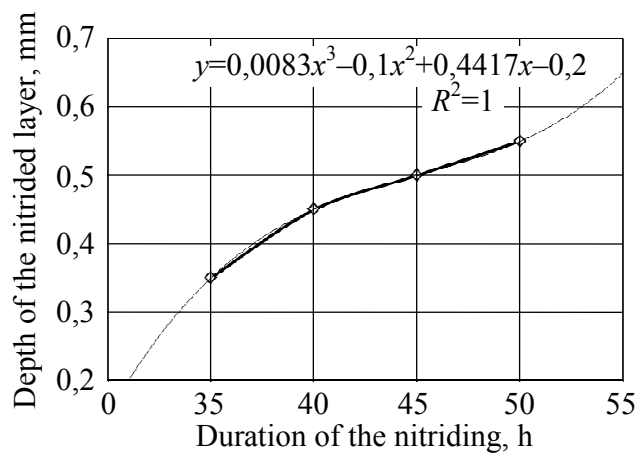

Fig. 1. The total depth of the nitrided layer of steel $20 K h 2 N 4 A$ depending on the duration of the nitriding at $510 \ldots 530{ }^{\circ} \mathrm{C}$

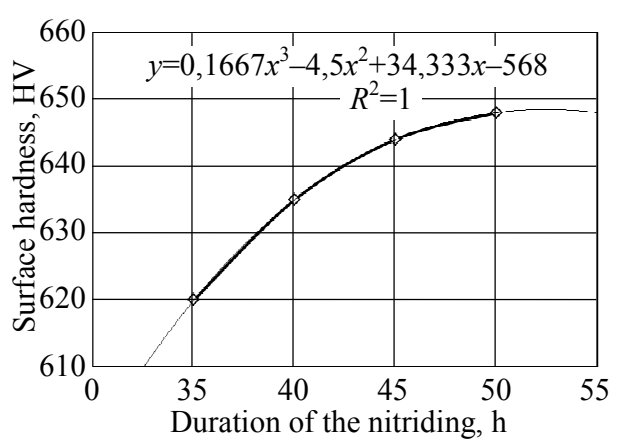

Fig. 2. Changing the surface hardness of steel $20 K h 2 N 4 A$ depending on the duration of the nitriding at $510 \ldots 530{ }^{\circ} \mathrm{C}$

With increasing duration of gas nitriding the diffusion of atomic nitrogen contributes to the growth of overall depth of the diffusion layer $\delta$ and surface hardness $\mathrm{HV}$ of steel 20Kh2N4A and varies according to the third degree polynomial formulas which are shown at the figures.

Thus, the following conclusion can be made. The optimal duration of CTP for steel 20Kh2N4A by the developed technology is the duration of $48 \mathrm{~h}$. at the temperature of $530^{\circ} \mathrm{C}$, which provides enormous surface hardness with slow distribution of microhardness to the depth of the nitrided layer up to $0,55 \mathrm{~mm}$. The structure is more saturated and uniform and is a sorbitol tolerance with nitride in the diffusion layer. The dependence of the diffusion layer depth and the surface hardness from gas nitriding duration is shown at Fig. 3.

\section{Conclusions:}

- Preliminary heat treatment (improving) before nitriding the alloy steel $20 \mathrm{Kh} 2 \mathrm{~N} 4 \mathrm{~A}$ provides hardness of products core up to 279...321 HV due to the forming of perlite-sorbitol structure with carbides of alloying elements.

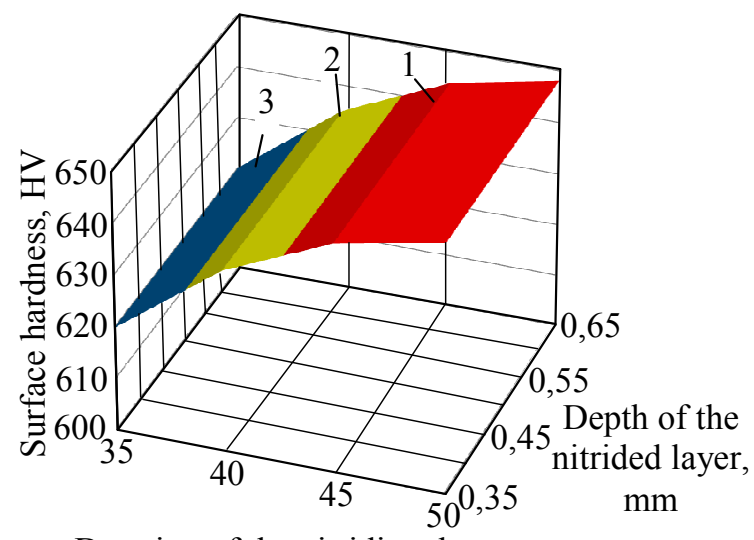

Duration of the nitriding, $\mathrm{h}$

Fig. 3. The dependence of the diffusion layer depth and surface hardness from gas nitriding duration: $640 \ldots 650$ (1); $630 \ldots 640$ (2); 620..630 (3) 
- By saturation of the surface of steel 20Kh2N4A sample by atomic nitrogen it is possible to obtain the diffusion layer with thickness of $0,55 \mathrm{~mm}$ and surface hardness of $648 \mathrm{MPa}$.

- With increasing of duration of CTP from 35 to $48 \mathrm{~h}$. at $510 \ldots 530{ }^{\circ} \mathrm{C}$ increases the depth of nitrided layer from 0,35 to $0,55 \mathrm{~mm}$, accordingly.

- Optimal mode of strengthening the boundary layer of steel 20Kh2N4A while nitriding at a shaft furnace SShAM at the optimum degree of ammonia dissociation $25 \ldots .35 \%$ we consider the mode at the temperature for two steps of $510 \ldots 530^{\circ} \mathrm{C}$ with total duration of $48 \mathrm{~h}$., after which the surface layer hardness is $648 \mathrm{HV}$ with total depth of diffusion layer $\sim 0,55 \mathrm{~mm}$.

\section{Література}

1. Новые идеи о механизме образования структуры азотированных сталей / С.А. Герасимов, А.В. Жихарев, Е.В. Березина и др. // Металловедение и термическая обработка металлов. 2004. 一 № 1(583). - С. $13-18$.

2. Крукович, М.Г. Моделирование процесса азотирования / М.Г. Крукович // Металловедение и термическая обработка металлов. - 2004. — № 1(583). - С. $24-31$.

3. Формирование однофазного слоя $\gamma$ '-нитрида при контролируемом азотировании в газовой среде / Й. Михальски, Й. Тасиковски, П. Вах и др. // Металловедение и термическая обработка металлов. - 2005. — № 11(605). - С. $35-38$.

4. Шпис, Х.-Й. Контролируемое азотирование / Х.-Й. Шпис, Х. Ле Тьен, Х. Бирманн // Металловедение и термическая обработка металлов. - 2004. - № 7(589). - С. 7 - 11.

5. Baranowska, J. Functional characteristics of nitride layers on austenitic steel produced by gas nitriding / J. Baranowska // Material Science. — 2005. — Vol. 11, No. 3. — PP. 226 - 229.

6. Базалеева, К.О. Механизмы влияния азота на структуру и свойства сталей (обзор) / К.О. Базалеева // Металловедение и термическая обработка металлов. — 2005. — № 10(604). C. $17-24$.

7. Газобарическое азотирование сталей / С.А. Герасимов, В.А. Голиков, М.А. Гресс и др. // Металловедение и термическая обработка металлов. - 2004. - № 6(588). - С. 7 -9.

8. Куксенов, Л.И. Влияние условий нагрева при азотировании на структуру и износостойкость поверхностных слоев на стали 38Х2МЮА / Л.И. Куксенов, М.С. Мичугин // Металловедение и термическая обработка металлов. — 2008. — № 2. - С. $29-34$.

\section{References}

1. Gerasimov, S.A., Zhikharev, A.V., Berezina, E.V. Zubarev, G.I. and Pryanichnikov, V.A. (2004). New ideas on the mechanism of structure formation in nitrided steels. Metal Science and Heat Treatment, 46(1-2), 13-17.

2. Krukovich, M.G. (2004). Simulation of the nitriding process. Metal Science and Heat Treatment, 46(1-2), 25-31.

3. Michalski, J., Tacikowski, J., Wach, P., Lunarska, E. and Baum, H. (2005). Formation of single-phase layer of $\gamma^{\prime}$-nitride in controlled gas nitriding. Metal Science and Heat Treatment, 47(11-12), 516-519.

4. Spies, H.-J., Thien, H.L. and Biermann, H.B. (2004). Controlled nitriding. Metal Science and Heat Treatment, 46(7-8), 272-276.

5. Baranowska, J. (2005). Functional characteristics of nitride layers on austenitic steel produced by gas nitriding. Material Science, 11(3), 226-229.

6. Bazaleeva, K.O. (2005). Mechanisms of the influence of nitrogen on the structure and properties of steels (A Review). Metal Science and Heat Treatment, 47(9-10), 455-461.

7. Gerasimov, S.A., Golikov, V.A., Gress, M.A., Mukhin, G.G. and Snop, V.I. (2004). High-pressure gas nitriding of steels. Metal Science and Heat Treatment, 46(5-6), 227-229.

8. Kuksenova, L.I. and Michugina, M.S. (2008). Effect of heating conditions in nitriding on the structure and wear resistance of surface layers of steel 38Kh2MYuA. Metal Science and Heat Treatment, 50(1-2), 68-72. 